\title{
Review Article Nanotechnology Applications in Interior Design of Hospitals
}

\author{
Reem Ahmed El-Abbasy \\ Architecture Department \\ Ain Shams University Cairo, \\ Egypt
}

\author{
Ahmed Atef Faggal \\ Architecture Department \\ Ain Shams University Cairo, \\ Egypt
}

\author{
Yasser Mansour \\ Architecture Department \\ Ain Shams University Cairo, \\ Egypt
}

\begin{abstract}
Interior finishes are very important aspects of the healthcare facilities environment. Floors and walls coverings are major elements that play a role to keep a healthy environment inside spaces of hospitals. Thus, it is necessary to be the priority to the criteria of selection finishing materials during the design process. Finishing materials and its properties are considered one of the most factor impacted on the interior design at hospitals. Especially, in critical areas at hospitals need specific finishes characteristics, such as surgical, Intensive Care, Emergency, and Inpatient Units. Healthcare facilities are required special specification for interior spaces and finishing materials to prevent problems as moisture penetration, water infiltration, and the growth of mildew and mold that this is considered as some of several elements responsible for occurring Hospital-Acquired Infections (HAIs).
\end{abstract}

This study aims to suggest the best building interior design considerations for improving the comfort and the satisfaction of healthcare patients and occupants in their working environments and to prevent the transmission of diseases in hospitals. Based on this purpose, this article set the nano-materials to evaluate it and search for its achieving that purpose.

Nano-materials play an important role in hygienic design in interior spaces. In this scope, the main inquiry is that which kinds of Nano-materials or its applications are the best choices for the interior design especially in critical areas of hospitals? The goal of this study was to determine if nano-materials can be significantly effective in enhancing the interior design of healthcare facilities, by improving the performance of the finishing materials and reduce the damages and problems occurring during their life cycle. The librarian searching and tests results from nano companies labs are used to achieve this aim.

It was concluded that nano-materials used in interior finishing materials are classified into two groups. One is used to solve the problems of traditional materials that contribute to the transmission of infection as they have characteristics that limit the occurrence of problems of different finishing materials that occur in hospitals and also reduce the existence of the bacteria, mold and fungi on the surface and prevent the existence of environment suitable for its growth, while the other is used in cleaning and disinfection and reduce the risks of chemicals hazards that emit harmful gases that affect human health. Thus, the use of nanotechnology helps to maintain a healthy environment in hospitals.

Index Terms-Nano-materials, Hygienic Properties, Antimicrobial, Hospital-Acquired Infections

\section{INTRODUCTION}

Health is a very important need for human and keeps it as well, however, it is common to infect by the illness through going to the therapeutic and medical places that it is called healthcare-associated infection (HAIs).Infections occurred during people received treatment in healthcare facilities for other diseases or any anther Health complaint. The people may be acquired infections through Inpatient of Hospitals or Ambulatory settings or Long-term care facilities or HAIs of unknown origin. Human life is surrounded by germs in the air, water, soil, and their bodies. They may be helpful at some times and make the human body staying healthy or harmful and causing infection especially the small portion of germs. Otherwise, Healthcare design is a new approach that investigates the needs of psychological and social of a human, as a new perspective on healthcare, in addition to concerning conventional biomedical and economic aspects [1].As part of this approach, interior design considered a major vital element in the whole life cycle of a healthcare building [2].Interior finishes are very important aspects of the healthcare facilities environment. Floors, walls coverings, and its accessories are major elements that play a role to keep a healthy environment inside spaces of hospitals. Thus, it is necessary to be the priority to the criteria of selection finishing materials during the design process. Nanotechnology ability in controlling materials that can change the world. Through used materials in Nano-length scale which improve the characteristics of material and developing them [3]. The researches on Nanoscaled materials reached that the novel materials are different chemical and physical properties, more efficiency, and better performance from conventional materials. Application of Nano-materials in interior design of hospitals is considered a major issues to achieve the hygienic properties and maintain healthy environment in hospitals.

\section{FINISHING MATERIALS}

Materials importance in life quality of human existence is undeniable. The urge of this concept is in the materials interaction with indoor and outdoor building environment. Thus appropriate selection of materials are major issues. The common materials used in constructions are classified as a general by Fernandez (2006):

- Polymers: Thermoplastics/Elastomers/Thermosets.

- Natural Materials: Wood/ Biopolymers/Natural fibres/ Earthen materials.

- Ceramics: Concrete/Fired clay/ Stone/ Glass.

- Metals: Ferrous/ Nonferrous. 


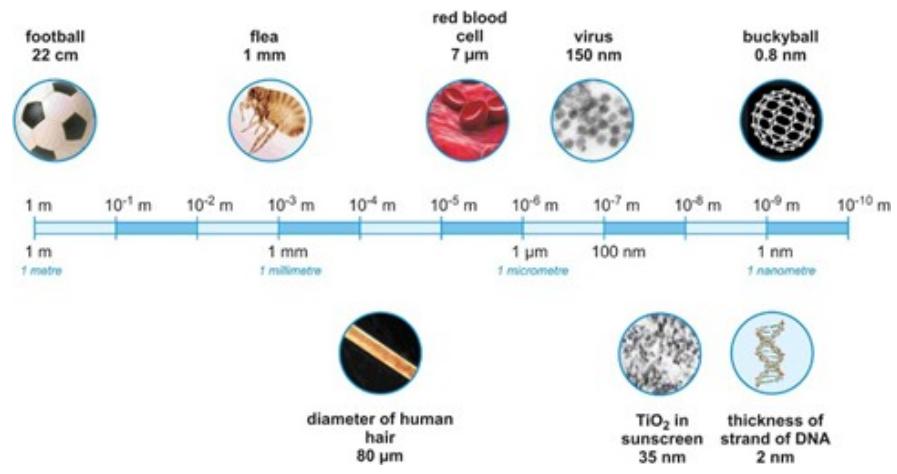

Fig. 1. Scale Ladder diagram that illustrated the size of the nano scale [6]

- Composites: GFRP/CFRP/ Fiber glasses/ others.

The process of selecting a suitable finish depends on many aspects thus this process needs to criteria that based on prioritized for facilities which must be investigated on a logical basis involve the following [4]:

- Environmental Considerations : Natural resources/ Safety/Energy consumption/Durability.

- Durability: Resistance to wear/ Adhesion of coatings/Weathering/ Mechanical properties.

- Fire safety

- Habitability: Thermal properties/ Hygiene/Acoustic properties/ Water permeability/Safety/Comfort.

- Compatibility.

However, building finishes are usually seen as a separate and final application to the building structure (Dean, 1996).However, instances of the finish are integral to the structure, and play an essential role in the healthcare environment, and contribute significantly to healthcare services delivery and the preservation for staff and patients [5]. The main requirements in the interior spaces is illustrated in Table. I.

\section{III. $\mathrm{N}$ ANOTECHNOLOGY}

Nanotechnology means the ability to create the materials and devices through changing the structure of molecules, atoms, and super-molecular which named by nano-scale to control the properties of matter [6].Nanotechnology has a lot of inclusive definitions mentioned in previous researches, however, the main concept is the changing of particles size as shown in Fig.1.In other words, the nano-meter (nm) scale dramatically impacts on the properties of materials that equal 10-9 meter(m) [7].

\section{APPliCATIONS OF NANO-MATERIALS}

\section{A. Nano Coating}

Coatings are the thin layers which deposited on the essential material to improve the surface attributes and its appearance [8]. There are types of Nano coating layers as shown in Fig.2 which improve the surface characteristics. Nano-coating is considered the coating with Nano-structured that applied on surfaces as summarized in Table.II [9].
TABLE I

The General Classify of Interior Spaces at Hospitals And REQUIREMENTS.

\begin{tabular}{|c|c|c|c|}
\hline & Category & Space & $\begin{array}{l}\text { Finishing } \\
\text { requirements }\end{array}$ \\
\hline 1 & $\begin{array}{c}\text { Highly sensitive } \\
\text { areas }\end{array}$ & $\begin{array}{l}\text { - Operating theatres } \\
\text { - Surgical washrooms } \\
\text { - Intensive care units } \\
\text { - Emergency ward } \\
\text { - Trauma rooms } \\
\text { - Aseptic rooms }\end{array}$ & $\begin{array}{l}\text { - Hygienic } \\
\text { requirements. } \\
\text { - Protection } \\
\text { against the } \\
\text { settlement } \\
\text { of germs } \\
\text { \& bacteria. } \\
\text { - Durability. } \\
\text { - Be disinfectant } \\
\text { proof. }\end{array}$ \\
\hline 2 & Kitchen areas & $\begin{array}{l}\text { - Kitchens and food } \\
\text { preparation } \\
\text { - Catering areas } \\
\text { - Cold stores and } \\
\text { store rooms }\end{array}$ & $\begin{array}{l}\text { - Hygienic } \\
\text { environment. } \\
\text { - Resistant } \\
\text { to moisture } \\
\text { as mold } \\
\text { and bacteria. } \\
\text { - Easy to clean. }\end{array}$ \\
\hline 3 & $\begin{array}{l}\text { Sensitive } \\
\text { areas }\end{array}$ & $\begin{array}{l}\text {-Preoperative areas } \\
\& \text { recovery rooms } \\
\text { - Sterilizing rooms } \\
\text { - Laboratories } \\
\text { - Treatment rooms } \\
\text { - Functional } \\
\text { diagnostics } \\
\text { - Patient changing } \\
\text { rooms } \\
\text { - Utility \& disposal } \\
\text { area }\end{array}$ & $\begin{array}{l}\text { - Hygienic } \\
\text { requirements. } \\
\text { - Resistant } \\
\text { to bacteria. } \\
\text {-Resilient } \\
\text { to regular } \\
\text { cleaning } \\
\text { \& mechanically } \\
\text { loadable }\end{array}$ \\
\hline 4 & Moist rooms & $\begin{array}{l}\text { - Public washrooms } \\
\text { - Bathrooms } \\
\text { - Laundry }\end{array}$ & $\begin{array}{l}\text {-Protection } \\
\text { against mould. } \\
\text {-Be water- } \\
\text { repellent. }\end{array}$ \\
\hline 5 & $\begin{array}{l}\text { Common } \\
\text { areas }\end{array}$ & $\begin{array}{l}\text { - Care rooms } \\
\text { - Wards } \\
\text { - Waiting rooms \& } \\
\text { recreation rooms } \\
\text { - Reception area }\end{array}$ & $\begin{array}{l}\text { - Be insensitive. } \\
\text { - Washable. }\end{array}$ \\
\hline 6 & $\begin{array}{c}\text { Staff areas } \\
\text { Administration } \\
\text { Technical areas } \\
\text { Storage areas }\end{array}$ & $\begin{array}{l}\text { - Staff rooms } \\
\text { - Corridors } \\
\text { - Offices } \\
\text { - Stairwells } \\
\text { - Technical rooms } \\
\text { - Store rooms }\end{array}$ & $\begin{array}{l}\text { - The suitability } \\
\text { for cleaning. } \\
\text { - Mechanical } \\
\text { loading } \\
\text { aspects. } \\
\text { - Fireproof } \\
\text { aspects. }\end{array}$ \\
\hline
\end{tabular}

These surfaces can, for example, be super-hydrophobic or super-hydrophilic. Super-hydrophobic means water-repelling surfaces and super-hydrophilic means water-attracting surfaces that lead the surfaces to be easier cleaning. The spray coatings are also created by nano-structured and applied them to microstructured previous surfaces. Nano-coating have a several advantages as:

- A better surface appearance.

- Good chemical resistance.

- Easy to clean.

- The reduction in permeability to the corrosive environment consequently better corrosion properties.

- Anti-fogging, Anti-graffiti, Anti-fouling, Anti-skid properties.

- Mechanical properties like scratch resistance.

- Anti-reflective. 


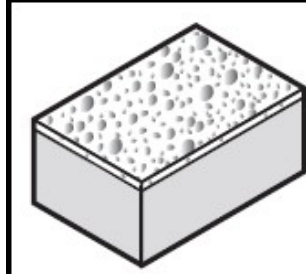

Nanoalloys

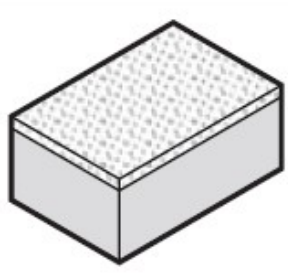

Nanocomposite

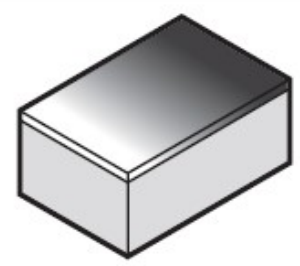

Functionally graded

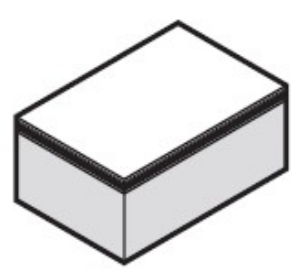

Multilayer

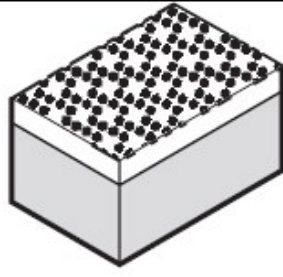

Nanotextured

Fig. 2. Types of Nano coating layers

TABLE II

NANO-COATING

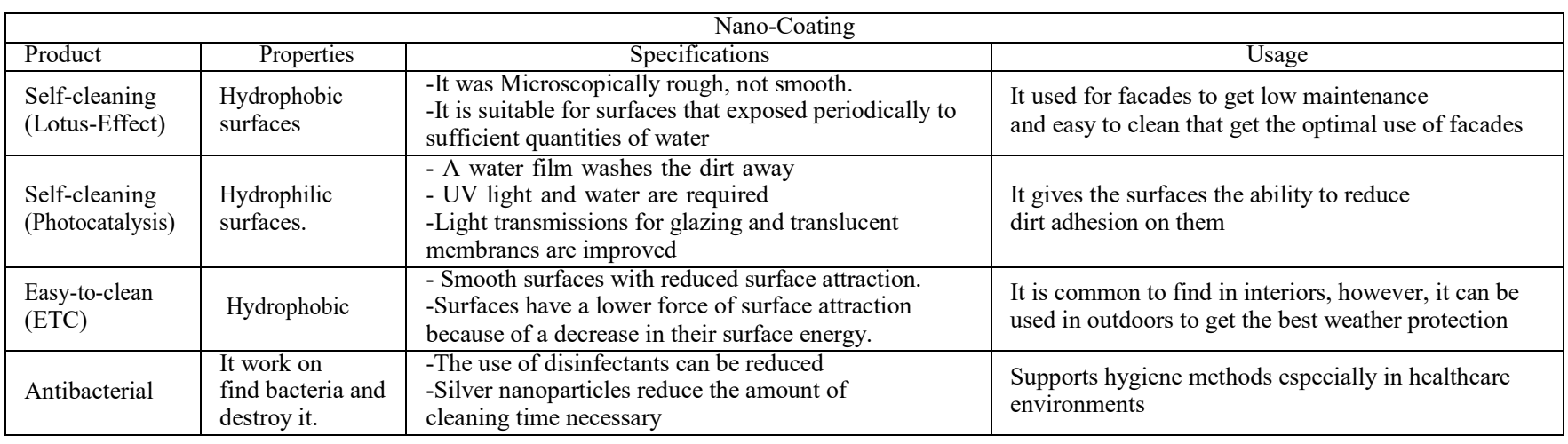

- Chromate and lead-free.

- A best thermal and electrical conductivity.

- The best retention of gloss.

- Increase in modulus and thermal stability.

- Optical clarity.

Depending on the required function, the coatings which depend on the nanotechnology consist of the following materials: Titanium dioxide, carbon black, silicon dioxide, zinc oxide, iron oxide, silver, and other materials as illustrated in Table.III [10]. Nano coating is an environmentally friendly and unique solution for long-lasting protection from bacteria, mould bio contamination risk or virus and sustainable surface sanitization. The features and benefits of nano coating are illustrated in Table.IV.

The main issue in interior spaces of hospitals is the bacteria inhabiting on the various surfaces. Thus, nano-coating applied on several materials that are commonly used in interior spaces to be the advantage of its characteristics and its high performance especially against bacteria such as:

1) Marble: Nano coating make them very liquid repellent, anti-scratches, anti-stain, and glossy.

2) Windows \& Facades: Nano coating protects the surface from calcium build-up, hard water, sand, watermarks, and dirt. It gives a self-cleaning property for the surface.

3) Wood: It keeps the surface from UV rays and water from damaging, and it is more durability.

4) Stainless Steel: Nano coating gives gloss and additional protection by bound it to stainless steel.

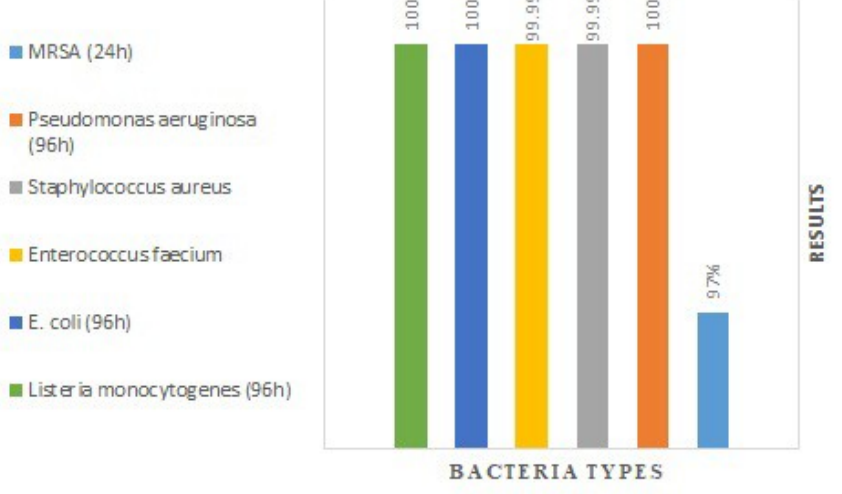

Fig. 3. The effect of nano coating for Bacteria-inhibiting on surfaces

The nano-coating is considered the best solution for antibacteria according to the tests made by the Institute for Hospital Hygiene and Inflection control as shown in Fig.3

The tests showed that the performance of nano-coating is significantly preferable compared to the performance of conventional paint as shown in graph Fig.4 [11].

\section{B. Nanomaterials in furniture}

The main properties of nanomaterials applied in finishing materials of furniture depending on the type of nanomaterials additives that illustrated in Table.V [14]. 
TABLE III

NANOMATERIALS APPLICATION IN COATINGS AND THEIR FUNCTIONS

\begin{tabular}{|c|c|c|c|}
\hline Nanomaterial (Examples) & Function & Effect & Industrial Applied \\
\hline $\begin{array}{l}\text { Oxides: } \\
\text { - Titanium dioxide (TiO2). } \\
\text { - Iron (II, III) oxide (Fe3O4, Fe2O3). } \\
\text { - Silicon dioxide (SiO2). } \\
\text { - Chromium (III) oxide (Cr2O3). }\end{array}$ & $\begin{array}{l}\text { - Color effect. } \\
\text { - Reproducible paints. }\end{array}$ & $\begin{array}{l}\text { - Prevent crack formation. } \\
\text { - Enhanced resistance to fading }\end{array}$ & $\begin{array}{l}\text { - Construction. } \\
\text { - Furniture. }\end{array}$ \\
\hline $\begin{array}{l}\text { - Organic/inorganic hybrid polymers. } \\
\text { - Colloidal /nanosilica silica embedded. } \\
\text { - Silanes e.g. fluorine compounds. } \\
\text { - Titanium dioxide (TiO2). }\end{array}$ & - Self-cleaning & $\begin{array}{l}\text { - Dirt \& water repellant. } \\
\text { - Anti-graffiti protection. } \\
\text { - Protection against fungi and algae. }\end{array}$ & $\begin{array}{l}\text { - Glass. } \\
\text { - Construction(facades) }\end{array}$ \\
\hline $\begin{array}{l}\text { - Silicon dioxide }(\mathrm{SiO} 2) \\
\text { - Aluminum oxide (A12O3). }\end{array}$ & - Scratch resistance & - Enhanced scratch resistance & $\begin{array}{l}\text { - Parquet flooring. } \\
\text { - Furniture. }\end{array}$ \\
\hline $\begin{array}{l}\text { - Titanium dioxide (TiO2). } \\
\text {-Silver (Ag). }\end{array}$ & $\begin{array}{l}\text { - Photocatalytic effect. } \\
\text { - Antimicrobial effect. }\end{array}$ & $\begin{array}{l}\text { - Removal of grease, algae, dirt, bacteria, } \\
\text { odorants, fungi, and pollutants. } \\
\text { - Transformation of ozone and NOx } \\
\text { into harmless compounds. }\end{array}$ & $\begin{array}{l}\text { - Wood preservation } \\
\text { - Glass } \\
\text { - Construction(facades, tiles, } \\
\text { noise barriers) }\end{array}$ \\
\hline Titanium dioxide (TiO2). & - Fire retardant & $\begin{array}{l}\text { - It create a layer of carbon foam which work to } \\
\text { insulation the heat on the surface of the wood } \\
\text { and followed by a layer of ceramic resist a flame. }\end{array}$ & $\begin{array}{l}\text { - Wood production } \\
\text { against fire . } \\
\text { - Construction. }\end{array}$ \\
\hline $\begin{array}{l}\text { - Titanium dioxide }(\mathrm{TiO} 2) \text {. } \\
\text { - Zinc oxide }(\mathrm{ZnO}) \text {. } \\
\text { - Iron oxide pigments. }\end{array}$ & $\begin{array}{l}\text {-UV protection. } \\
\text {-IR absorbing. }\end{array}$ & $\begin{array}{l}\text { - Control of indoor climate. } \\
\text { - IR blocking. } \\
\text { - Enhanced of UV resistance. }\end{array}$ & $\begin{array}{l}\text { - Glass. } \\
\text { - Plastics. } \\
\text { - Wood preservation. } \\
\text { - Construction (facades). }\end{array}$ \\
\hline
\end{tabular}

TABLE IV

SElf-SANitizing OF NANO COATING

\begin{tabular}{|l|l|}
\hline \multicolumn{2}{|c|}{ Self-Sanitizing of Nano Coating } \\
\hline \multicolumn{1}{|c|}{ Features } & \multicolumn{1}{c|}{ Environmental benefits } \\
\hline $\begin{array}{l}\text {-Powered by light } \\
\text {-Works with natural, UV } \\
\text { and fluorescent light }\end{array}$ & -Improves IAQ (indoor air quality) \\
\hline $\begin{array}{l}\text {-High performance } \\
\text {-Long lasting effect }\end{array}$ & -Reduces using of toxic chemical \\
\hline $\begin{array}{l}\text {-Environment friendly } \\
\text {-Harmless to human } \\
\text { beings and animals }\end{array}$ & $\begin{array}{l}\text {-Reduces the risk of surface } \\
\text { bio-contamination }\end{array}$ \\
\hline $\begin{array}{l}\text {-Decomposition of } \\
\text { endotoxin and germ } \\
\text { body }\end{array}$ & $\begin{array}{l}\text {-Reduces the time of cleaning } \\
\text { and disinfection process }\end{array}$ \\
\hline
\end{tabular}

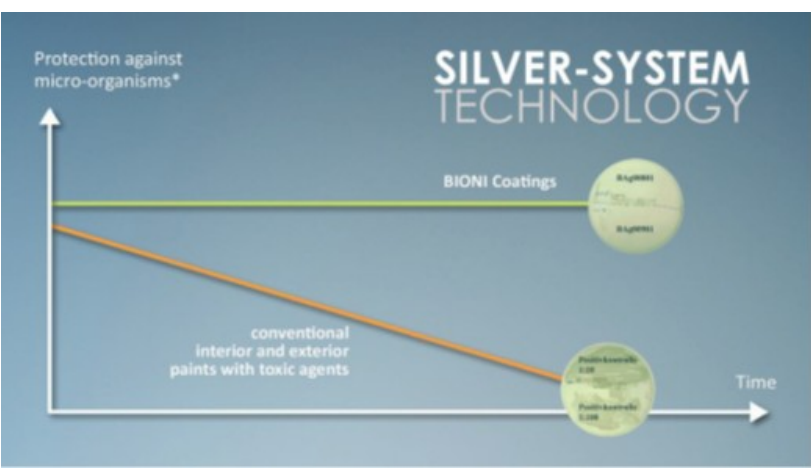

Fig. 4. Comparison between the performance of nano coating and conventional paint [11]

One of the common application of nano materials additives to furniture is nano in textiles as shown in the next section.

1) Nano Textiles: Nano materials provide solutions to different problems of textiles which users are faced during the use of conventional textiles. According to (Roya Dastjerdi, 2010),
Some of the advantages of the nano textiles are:

- To prevent unwanted and uncontrolled reproduction of microbes which can lead to dangerous health problems during using textiles.

- No discoloration and decrease in degradation.

- To maintain appropriate moisture and temperature.

- Reduce the risks of potential health.

- Avoidance of unpleasant odor production.

- Prevent stains on textiles because of spilled liquids.

- Prevent dirt or dust.

- Avoid mites in textiles.

These nano textiles materials have applications in curtains, carpets, upholstery, bedding, and medical uniforms as shown in Table.VI [12].

Through the interviewing with maintenance managers of many hospitals found that all furniture used the leather as a finishing materials to be easy clean and washable. The testes results showed that the Nano leather solve the problems of the conventional leather related to the growth of bacteria as shown in Fig. 5 \& 6.

\section{Nano insulation materials}

Nanomaterials are the novel materials with very low thermal conductivities that lead to limit the thickness of the wall to achieve a satisfactory thermal resistance that prevents the formation of a suitable environment for the growth of bacteria. Some of these materials are presented in Table.VII [13].

\section{DISCUSSION}

According to information on finishing materials used in hospitals through standard Codes of Hospital Design and designers, they suffered from several problems that related to the maintenance and cleaning process in hospitals which help the growth of bacteria, fungi, and microbes and aided 
TABLE V

Type of Nanomaterials Added to Finishing Materials of Furniture

\begin{tabular}{|l|c|c|c|c|c|c|}
\hline Nano-material & Anti-microbial & Easy to clean & Scratch Resistance & $\begin{array}{c}\text { Self-cleaning } \\
\text { Properties }\end{array}$ & Anti-graffiti & UV/ light Stability \\
\hline Silicon dioxide (SiO2) & & $\mathrm{X}$ & $\mathrm{X}$ & & $\mathrm{X}$ & \\
\hline Cerium oxide (CeO2) & & & & & & $\mathrm{X}$ \\
\hline $\begin{array}{l}\text { Titanium dioxid (TiO2)/ } \\
\text { Zinc oxide (ZnO) }\end{array}$ & $\mathrm{X}$ & & & $\mathrm{X}$ & & $\mathrm{X}$ \\
\hline Copper oxide (CuO) & $\mathrm{X}$ & & & & & \\
\hline Silver (Ag) & $\mathrm{X}$ & & & & & \\
\hline
\end{tabular}

TABLE VI

SEVERAL TYPES OF NANO PARTICLES USED IN THE TEXTILE SECTOR

\begin{tabular}{|c|c|c|c|}
\hline Nanoparticle & Fiber & Characteristic & $\begin{array}{l}\text { Application } \\
\text { in interior } \\
\text { design }\end{array}$ \\
\hline $\begin{array}{l}\text { Nanowires } \\
\text { Silver }\end{array}$ & Cotton & $\begin{array}{l}\text { - Anti-bacteria. } \\
\text { - Super } \\
\text { Hydrophobicity. } \\
\text { - UV light } \\
\text { resistant. } \\
\text { - High } \\
\text { electrical } \\
\text { conductivity. }\end{array}$ & $\begin{array}{l}\text { - Curtains. } \\
\text { - Upholstery. } \\
\text { - Table linen. }\end{array}$ \\
\hline $\begin{array}{l}\text { Nanoparticle } \\
\text { Titanium } \\
\text { dioxide }\end{array}$ & $\begin{array}{l}\text { Cotton } \\
\text { Wool }\end{array}$ & $\begin{array}{l}\text { - Anti-bacteria. } \\
\text { - Photocatalytic. } \\
\text { - Self-cleaning } \\
\text { surfaces. } \\
\text { - Semi- } \\
\text { conductor. }\end{array}$ & $\begin{array}{l}\text { - Upholstery. } \\
\text { - Carpets. }\end{array}$ \\
\hline $\begin{array}{c}\text { Copper } \\
\text { Nanoparticles }\end{array}$ & Nylon & $\begin{array}{l}\text {-Anti fungal. } \\
\text {-Anti microbial. }\end{array}$ & $\begin{array}{l}\text { - Curtains. } \\
\text { - Cushion. }\end{array}$ \\
\hline $\begin{array}{c}\text { Gold } \\
\text { Nanoparticles }\end{array}$ & Wool & $\begin{array}{l}\text {-UV light } \\
\text { resistant. } \\
\text {-Stable color. }\end{array}$ & $\begin{array}{l}\text { - Upholstery. } \\
\text { - Carpets. } \\
\text { - Bedding. }\end{array}$ \\
\hline $\begin{array}{c}\text { Silver } \\
\text { Nanoparticles }\end{array}$ & $\begin{array}{l}\text { Cotton } \\
\text { Nylon } \\
\text { Polyester } \\
\text { Silk } \\
\text { polyamide } \\
\text { other } \\
\text { synthetics }\end{array}$ & $\begin{array}{l}\text {-Anti bacterial } \\
\text { activity. } \\
\text {-Anti fungal. }\end{array}$ & $\begin{array}{l}\text { - Curtains. } \\
\text { - Bedding. } \\
\text { - Carpets. }\end{array}$ \\
\hline $\begin{array}{l}\text { Nanoparticles } \\
\text { of Titanium } \\
\text { dioxide } \\
\text { and silicon } \\
\text { oxide }\end{array}$ & $\begin{array}{l}\text { Cotton } \\
\text { Polyester }\end{array}$ & $\begin{array}{l}\text { - Thermal } \\
\text { stability } \\
\text { surfaces } \\
\text { - Long life } \\
\text { time. } \\
\text {-Low toxicity. } \\
\text {-UV protection. } \\
\text {-Excellent } \\
\text { optical } \\
\text { properties. }\end{array}$ & $\begin{array}{l}\text { - Making } \\
\text { furniture. } \\
\text { - Curtains. } \\
\text { - Carpets. }\end{array}$ \\
\hline $\begin{array}{l}\text { Nano Aluminum } \\
\text { oxide }\end{array}$ & Polyester & $\begin{array}{l}\text { - Water resistant. } \\
\text { - Superior } \\
\text { mechanical } \\
\text { strength. } \\
\text { - High load } \\
\text { capacity. }\end{array}$ & $\begin{array}{l}\text { - Application in } \\
\text { aerospace, } \\
\text { automotive, } \\
\text { naval, and } \\
\text { other } \\
\text { industries. }\end{array}$ \\
\hline $\begin{array}{c}\text { Silver } \\
\text { Nanoparticles } \\
\text { chitosan }\end{array}$ & Cotton & $\begin{array}{l}\text { - Anti-bacterial. } \\
\text { - Comfortable. }\end{array}$ & $\begin{array}{l}\text {-Application } \\
\text { in medical } \\
\text { scrubs }\end{array}$ \\
\hline $\begin{array}{l}\text { Zinc oxide } \\
\text { Titanium dioxide } \\
\text { and Silver } \\
\text { Nanoparticles }\end{array}$ & $\begin{array}{l}\text { Cotton } \\
\text { Wool }\end{array}$ & - Anti-bacterial & $\begin{array}{l}\text {-Medical } \\
\text { applications. } \\
\text {-Textiles and } \\
\text { clothing wear } \\
\text { applications. }\end{array}$ \\
\hline
\end{tabular}

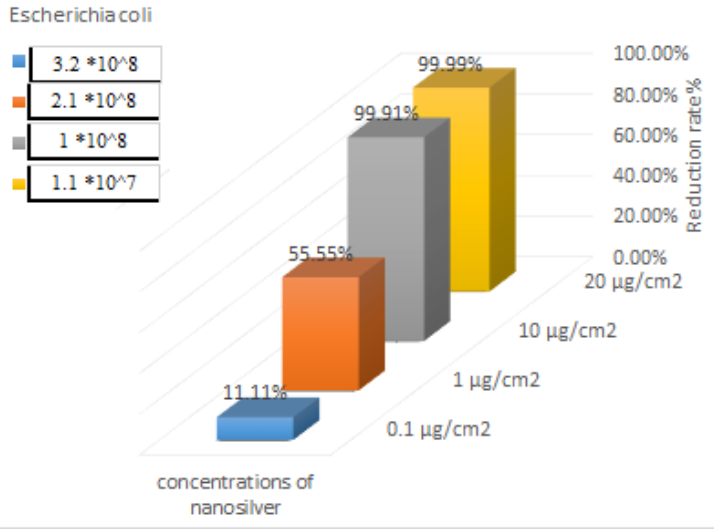

Fig. 5. The chart shows the Escherichia coli bacterial reduction on furniture leather samples which treated with various concentrations of nanosilver $(\mathrm{nAg})$ solution

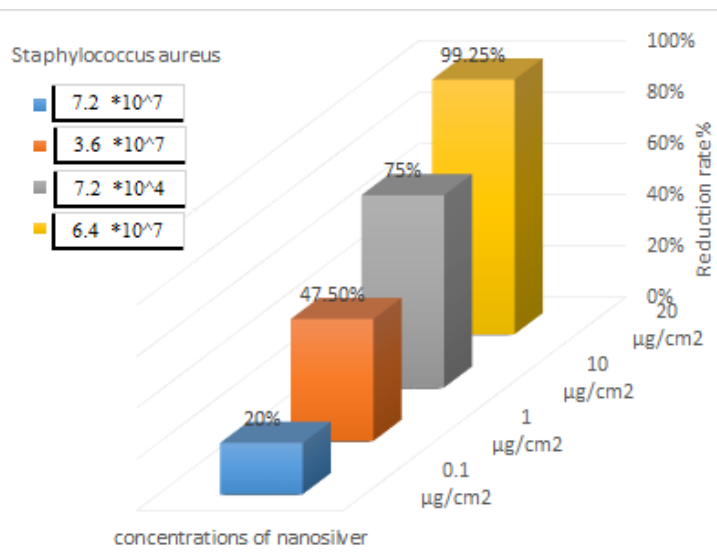

Fig. 6. The chart shows the Staphylococcus aureus bacterial reduction on furniture leather samples which treated with various concentrations of nanosilver (nAg) solution

to transmit the infectious. Nano-materials is considered the best solution because all Nano materials can be used as a solution for different problems of finishing materials in hospitals that illustrated in the matrix Fig.7 which showed the relationship between common Nano-products properties, and functionalities that are important to architects and interior designers. The Matrix illustrated that the self-cleaning, antimicrobial, anti-bacterial, anti-fungi, and self-healing are the main functions for Nano coating, Nano textiles, Nano paints, 

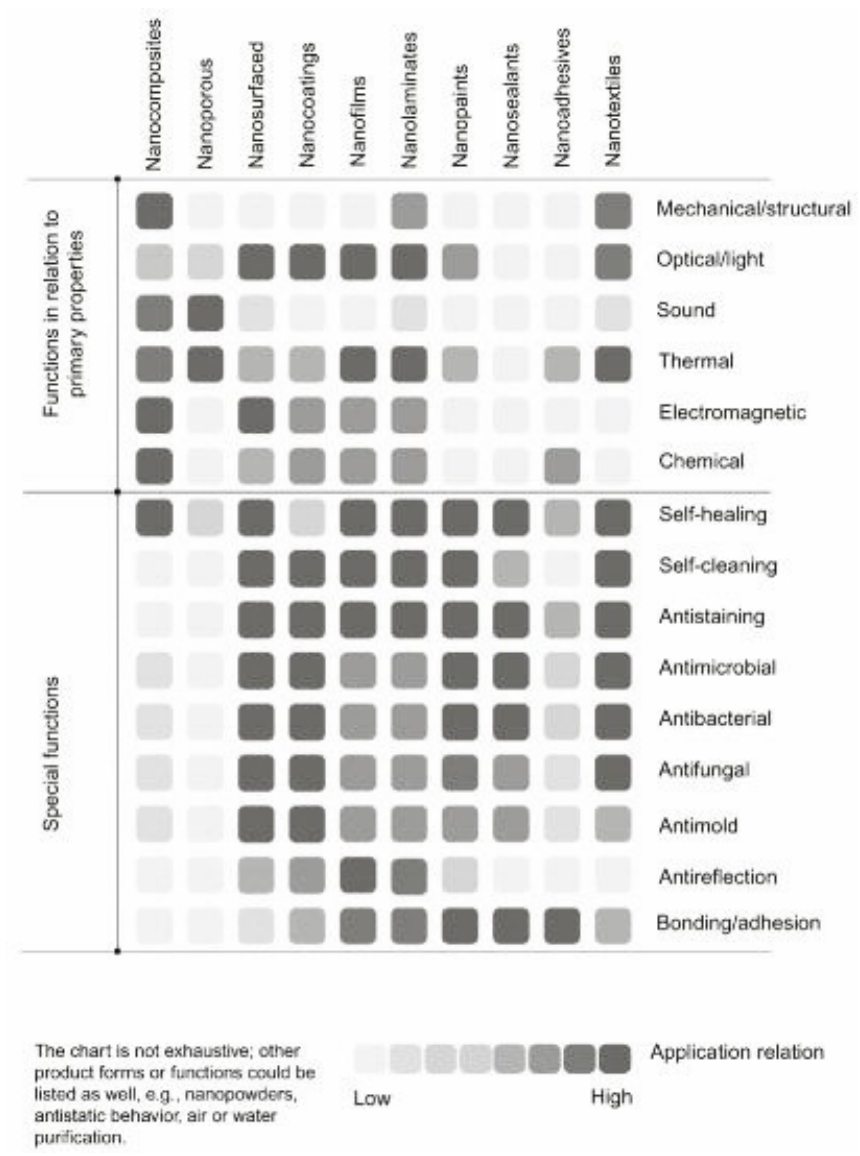

Fig. 7. Matrix illustrated the relationship between common Nano-products properties, and functionalities which are important to architects and interior designers [9]

and Nano sealants.

Nano-materials is considered the best solution because all nano materials can be used as a solution for different problems of finishing materials in hospitals. However, the important point is how to select the nano materials suitable for each space depending on its function. The various nano materials are illustrated in Table.II and its function.

\section{CONCLUSION}

The nanotechnology is producing hygienic products without harming human health or the environment. In addition, it is considered the solution for environmental problems especially that related to building problems. This study focused on mentioning the impacts of nanotechnology on the finishing materials performance in hospitals. The interior design appearance and light filtering, thermal insulations, sound insulations, and healthy environment can be improved by using nanocomposites, According to studies and tests on nano-materials performance in the interior spaces, it is categorized into two groups. The first one is to use the nano-materials for enhancing the properties of finishing materials and their functionality, the other one is to use these materials for maintenance purpose for finishing materials problems occurring in hospitals, both of
TABLE VII

Specifications of Common Materials Used Nano Thermal

\begin{tabular}{|c|c|c|}
\hline \multicolumn{3}{|c|}{ Nano-insulation } \\
\hline Material & Properties & Features \\
\hline Aerogel & $\begin{array}{l}\text { Hydrophobic } \\
\text { surfaces }\end{array}$ & $\begin{array}{l}\text { - It used for windows } \\
\text { because of its transparency. } \\
\text { - Lightweight. } \\
\text { - Very effective insulation. }\end{array}$ \\
\hline $\begin{array}{l}\text { Vaccum } \\
\text { Insulated } \\
\text { Panel }\end{array}$ & $\begin{array}{l}\text { Hydrophilic } \\
\text { surfaces. }\end{array}$ & $\begin{array}{l}\text { - It has a highly slim profile. } \\
\text { - Fits in narrow spaces } \\
\text { for novel builds. } \\
\text { - High performance } \\
\text { for thermal insulation. }\end{array}$ \\
\hline Nansulate & Hydrophobic & $\begin{array}{l}\text { - Non-toxic. } \\
\text { - Composing a thin layer } \\
\text { for insulation. } \\
\text { - High resistance against } \\
\text { microbiological attack. } \\
\text { - Smooth surfaces which } \\
\text { featured with reducing } \\
\text { the attraction of surface. }\end{array}$ \\
\hline
\end{tabular}

them to improve the characteristics of the finishing materials and enhance the quality of the interior space in hospitals which impact on the indoor quality for spaces and human health, especially, hospitals are considered the place where the infections were occurring in high percentage. The tests by using nano silver $(\mathrm{nAg})$ is indicated that nano silver decrease and destroyed the growth of bacteria that meaning nano- silver is the most nano-material a preferable solution against bacteria inhabiting in various hospital spaces. Finally, it is recommended for the architects, and interior designers to be aware of the benefits of using these materials and its impact on the human health and surrounding environment for applying them.

\section{REFERENCES}

[1] Lavy, S. and Dixit, M. K. (2012). Wall finish selection in hospital design: a survey of facility managers.HERD: Health Environments Research \& Design Journal, 5(2):8098.

[2] Ulrich, R. S., Zimring, C., Zhu, X., DuBose,J., Seo, H.-B., Choi, Y.S., Quan, X., and Joseph, A. (2008).A review of the research literature on evidence-based healthcare design. HERD: Health Environments Research \& Design Journal, 1(3):61125.

[3] Roco, M. C. (1999). Nanoparticles and nanotechnology research. Journal of Nanoparticle Research, 1(1), 1-6

[4] Trubiano, F. (2006). Material architecture: Emergent materials for innovative buildings and ecological construction.

[5] Salonen, H., Lahtinen, M., Lappalainen, S., Nevala, N., Knibbs, L.D., Morawska, L. and Reijula, K., 2013. Physical characteristics of the indoor environment that affect health and wellbeing in healthcare facilities: A review. Intelligent Buildings International, 5(1), pp.3-25.

[6] Marek Lichtarowicz "Nanomaterials", http://www.essentialchemicalindustry.org/materials-andapplications/nanomaterials.html.

[7] Ge, Z., \& Gao, Z. (2008). Applications of nanotechnology and nanomaterials in construction. First Inter. Confer. Construc. Develop. Countries, $235-240$.

[8] M.C. Roco, S. Williams, and P. Alivisatos, Nanotechnology research directions: vision for nanotechnology in the next decade,IWGNWorkshop Report, U.S. National Science and Technology Council, Washington, DC, 1999.

[9] Leydecker, Sylvia. Nano Materials in Architecture, Interior Architecture and Design. BirkhauserVerlag AG, 2008.

[10] Deutsches Lackinstitut (2012): Brandschutz-Beschichtungen 40 Minuten knnen Leben retten. Lack im Gesprch, Informationsdienst Deutsches Lackinstitut Nr. 112, Seite 5. 
[11] Silver-System-Technology, http://www.bioni.de/en/silver-systemtechnology.html.

[12] Melchor-Alemn, M. A., Mesta-Torres, L., \& Martel-Estrada, S. A. APPLICATIONS OF NANOPARTICLES IN TEXTILES FOR INTERIOR DESIGN

[13] Rostam, N. G., Mahdavinejad, M. J., \& Rostam, M. G. (2015). Commercializing usage of nano-insulating materials in building industry and future architecture. Procedia Materials Science, 11, 644-648.

[14] EFBWW: 2011 - Nano in Furniture - state of the art 2012, http://www.efbww.org/default.asp?Issue=Nano 